\title{
PSYCHOLOGICAL EVALUATION AND COPE WITH TRIGEMINAL NEURALGIA AND TEMPOROMANDIBULAR DISORDER
}

\author{
Adriana Ronchetti de Castro', Silvia Regina Dowgan Tesseroli de Siqueira ${ }^{2}$, \\ Dirce Maria Navas Perissinotti ${ }^{3}$, José Tadeu Tesseroli de Siqueira ${ }^{4}$
}

\begin{abstract}
Objective: To determine the psychological aspects of orofacial pain in trigeminal neuralgia (TN) and temporomandibular disorder (TMD), and associated factors of coping as limitations in daily activities and feelings about the treatment and about the pain. Method: 30 patients were evaluated (15 with TN and 15 with TMD) using a semi-directed interview and the Hospital Anxiety Depression (HAD) scale. Results: TN patients knew more about their diagnosis $(p<0.001)$. Most of the patients with TN considered their disease severe (87\%), in opposite to TMD ( $p=0.004$ ); both groups had a high level of limitations in daily activities, and the most helpful factors to overcome pain were the proposed treatment followed by religiosity $(p<0.04)$. Means of HAD scores were 10.9 for anxiety (moderate) and 11.67 for depression (mild), and were not statistically different between TMD and NT ( $p=0.20)$. Conclusion: TN and TMD had similar scores of anxiety and depression, therefore patients consider TN more severe than TMD. Even with higher limitations, patients with TN cope better with their disease then patients with TMD.
\end{abstract}

KEY WORDS: trigeminal neuralgia, TMD, surgery, orofacial pain, anxiety, depression, disease perception.

\begin{abstract}
Avaliação psicológica e enfrentamento na neuralgia trigeminal e disfunção temporomandibular
Resumo - Objetivo: Comparar aspectos psicológicos de dor orofacial entre neuralgia trigeminal (NT) e disfunção temporomandibular (DTM), e repercussões em atividades diárias, enfrentamento a representação da dor. Método: 30 pacientes foram avaliados (15 com NT, 15 com DTM) utilizando entrevista semi-dirigida e a Escala Hospitalar de Ansiedade e Depressão (HAD). Resultados: Pacientes com NT sabiam melhor sobre seu diagnóstico $(p<0,001)$. A maioria destes considerou sua doença grave $(87 \%)$, em oposição a pacientes com DTM ( $p=0,004)$; ambos tiveram um alto nivel de limitações durante atividades diárias, e o tratamento seguido da religiosidade foram considerados os aspectos mais positivos para superação da dor $(p<0,04)$. Não houve diferença estatística entre os grupos quanto a $\operatorname{HAD}(p=0,20)$, sendo a média dos índices foi 10,9 para ansiedade (moderada) e 11,67 para depressão (leve). Conclusão: Tanto pacientes com NT como pacientes com DTM apresentaram níveis semelhantes de ansiedade e depressão, entretanto pacientes com NT consideram sua doença mais grave do que os outros doentes. Mesmo com alto grau de limitações, seu enfrentamento da doença é melhor do que o enfrentamento de doentes com DTM.
\end{abstract}

PALAVRAS-CHAVE: neuralgia trigeminal, DTM, cirurgia, dor orofacial, ansiedade, depressão, representação da doença.

Chronic pain is one of the main causes of physical and psychosocial distress, absences at work and retirement because of handicap ${ }^{1,2}$. It causes intense suffering, anxiety and incapacitation ${ }^{3}$. Patients often need an interdisciplinary group and the focus of treatment should include quality of life and coping ${ }^{4}$. Therefore, there might be differences among the diseases and it should be investigat- ed not only in its physical but also in its psychological aspects and correlates.

Trigeminal neuralgia (TN) in an excruciating neuropathic pain with unknown etiology, and it is considered one of the worst causes of suffering associated to pain ${ }^{5}$. It often cases depression and even suicide in some cases. Its treatment is usually efficient in the beginning, be-

\footnotetext{
Hospital das Clínicas, Medical School, University of São Paulo, São Paulo SP, Brazil: 'Psychologist, Specialist in Hospital Psychology; ${ }^{2}$ DDS, PhD, Assistant Professor at Escola de Artes, Ciências e Humanidades, and Member of the Orofacial Pain Team; ${ }^{3}$ Psychologist, Headache League; ${ }^{4}$ DDS, PhD, Head of the Orofacial Pain Team.
}

Received 25 March 2008, received in final form 21 July 2008. Accepted 31 July 2008. 
ing carbamazepine is the drug of choice 6 . Unfortunatelly, more than $75 \%$ of the patients need neurosurgery to control their pain during the first 5 years ${ }^{7}$. The long history of pain and return of crises are important factors that indicate the need of support for these patients. Even after surgery, many of them have complications as numbness and masticatory abnormalities, such as chewing difficulties, weakness at the jaw, mouth opening limitations ${ }^{8}$, and pain can still come again. Temporomandibular disorder (TMD) is a general term for musculoskeletal pain of the masticatory system with multiple etiology. It is one of the most common diagnosis of chronic orofacial pain, associated to pychosocial, behavioral, cognitive and emotional factors ${ }^{9}$, and patients often have depression and/ or anxiety. Beyond physical abnormalities at the muscles and at the teeth and joints, emotional stress is also associated $^{10}$, and psychological assistance is necessary for most of the patients".

Different orofacial pains may have variable levels of anxiety and depression, and especially variation in ways of coping, daily limitations or perception of the disease. Thus, the aim of this study was to determine the psychological aspects in TN and TMD, and associated factors of coping as limitations in daily activities and feelings about the treatment and about the pain.

\section{METHOD}

The study was approved by the local Ethics Committee. All patients had more than 18 years old and all had agreed to participate of the study and signed the informed consent.

We evaluated 30 consecutive patients at the Orofacial Pain Team, Dentistry Division and at the Facial Pain Clinic, Neurology Division of a general hospital; 15 had typical trigeminal neuralgia (NT) following the IASP criteria ${ }^{12}$ (shock-like pain in paroxysms triggered by a light touch), and 15 had TMD, following the Academy of Orofacial Pain criteria ${ }^{13}$. Patients were divided into 2 groups:

Group I: 15 TN patients: 5 hospitalized and waiting for surgical treatment, 5 in clinical treatment and 5 just diagnosed as TN.

Group II: 15 TMD patients: 5 hospitalized and waiting for surgical treatment, 5 in clinical treatment and 5 just diagnosed as TMD.

\section{Exclusion criteria}

After the selection of the patient, we analyzed their medical history to verify other previous diagnoses as psychosis, dementia, delirium or conscious lowering, which could compromise data collection. No patients were excluded during the period of the research.

Data were collected using a semi-directed interview with questions about the pain perception, limitations of daily activities and ways of coping, and the HAD scale (Hospital Anxiety Depression Scale) $)^{14}$. These instruments, currently used in chronic patients at the hospital, were applied by the same psychologist for all patients, and the evaluation lasted 1 hour. Hospitalized patients were evaluated at the pre-operative period; patients clinically treated had their interview scheduled, and the recently diagnosed patients were evaluated immediately after the appointment for diagnosis.

The results were evaluated using frequencies and comparisons, and the HAD data were analyzed following the criteria of Botega et al. ${ }^{14}$ : anxiety can be scored as without symptoms ( $\leq 6.2)$, subclinical $(6.2<\times \leq 8.9)$, mild $(8.9<x \leq 11.5)$, moderate $(11.5<x \leq 13.8)$ or severe $(>13.8)$, and depression can be scored as without symptoms $(\leq 4.3)$, subclinical $(4.3<x \leq 6,4)$, mild $(6.4<x$ $\leq 11.8)$, moderate $(11.8<x \leq 12.3)$ or severe $(>12.3)$. Statistical analysis was performed with the chi-square test and T-test, and the significance level was $5 \%$.

\section{RESULTS}

General characteristics

Both groups of patients (TMD and TN) were similar about gender, ages, racial group or educational degree (Table 1). Symptoms of patients with TN were unbearable shock-like pain and symptoms of TMD patients were usually fatigue at the face and pain at masticatory muscles (temporalis and masseter) palpation. These patients were evaluated by the Research Diagnostic Criteria for TMD and all had diagnosis of Group I (myofascial pain without mouth opening limitation). Group I had statistically more history of previous surgery (46.7\%) than group II (1.3\%) $(p=0.004)$ (Table 1).

\section{Understanding of the diagnosis and treatment (semi-directed interview)}

The understanding about the surgery was different between patients with TMD and TN. Patients with TN associated the surgery more with the nerve and patients with TMD associated it more with pain $(p=0.006)$ (Table 1)

The perception of severity was almost the opposite between the groups $(p=0.004)$ (Table 2$)$.

\section{Limitations because of pain and coping \\ with it (semi-directed interview)}

The majority of patients with TMD and TN reported having severe limitations because of pain. Useful manners to overcome it were the treatment itself and their religiosity $(p<0.04)$ (Table 3). Religiosity is one important factor for coping with chronic diseases and was found in patients of this sample.

Most of the patients from both groups were away of work (Table 1).

All patients believed that the hospitalization and surgery were the only current ways to improve or cure their pain (Table 1). Tthe most common collateral effect reported was dizziness by the medication. 
Table 1. Comparison between patients with $T N$ and TMD about their general characteristics $(N=30)$.

\begin{tabular}{|c|c|c|}
\hline & TMD & $\mathrm{TN}$ \\
\hline \multirow[t]{2}{*}{ Gender } & Male: $2^{*}$ & Male: 6 \\
\hline & Female: 13 & Female: 9 \\
\hline \multirow[t]{5}{*}{ Ocupation } & Working: 5 & Working: 1 \\
\hline & Dismissed from work: 6 & Housewife: 6 \\
\hline & Unemployed: 3 & Dismissed from work: 4 \\
\hline & Retired: 1 & Unemployed: 2 \\
\hline & & Retired: 2 \\
\hline \multirow[t]{2}{*}{ Anterior hospitalization } & Yes: 2* & Yes: 7 \\
\hline & No: 13 & No: 8 \\
\hline \multirow[t]{3}{*}{ Reason for hospitalization } & Pain: 10 & Pain:9 \\
\hline & Surgery for pain: 3 & Surgery for the nerve: $6^{* *}$ \\
\hline & Another reason: 2 & Another reason: 0 \\
\hline \multirow[t]{4}{*}{ Expectations } & Alleviation of symptoms: 8 & Alleviation of symptoms: 6 \\
\hline & Cure: 4 & Cure: 7 \\
\hline & Worsening: 1 & Worsening: 0 \\
\hline & Normal life: 0 & Normal life: 2 \\
\hline \multirow[t]{4}{*}{ Fears } & Death/sequalae: 2 & Death/sequalae: 0 \\
\hline & No improvement: 9 & No improvement: 9 \\
\hline & Failure of treatment: 2 & Failure of treatment: 4 \\
\hline & Did not answer: 2 & Did not answer: 2 \\
\hline \multirow[t]{2}{*}{ Meaning of hospitalization } & Positive: 4 & Positive: 5 \\
\hline & Positive and negative: 4 & Positive and negative: 0 \\
\hline Belief about hospitalization & Possibility of cure: $15^{\star * *}$ & Possibility of cure: 15 \\
\hline
\end{tabular}

${ }^{*} \mathrm{p}=0.004 ;{ }^{* *} \mathrm{p}=0.006 ;{ }^{* * *} \mathrm{p}=0.01$

\section{Expectations and fears (semi-directed interview)}

Expectation, fears and positive impression of hospitalization were similar in both samples. All patients were expecting the cure and would be satisfied with the alleviation of part of their symptoms, and the most important fear was no improvement of pain. Hospitalization was associated with a great possibility to get pain alleviation by surgery $(\mathrm{P}=0.01)$ (Table 1).

\section{Anxiety and depression (HAD)}

Means of HAD scores were 10.9 for anxiety (moderate) and 11.7 for depression (mild) for the whole sample. TN anxiety (mean 12.8) and depression (mean 11.26) were higher than TMD (both means 10.53), but not statistically different $(p=0.20)$. There was no differences according to the need of surgery or not (Tables 4 and 5). Patients with facial pain had higher scores of anxiety and depression than patients from other clinics at the hospital (Table 5).

\section{DISCUSSION}

The most interesting result of this study was that, despite TN was considered more severe by the patients than TMD, the anxiety and depression scores were similar between them. Therefore, as expected, both facial pains
Table 2. Severity of pain, comparison of TN and TMD patients $(\mathrm{N}=30)$.

\begin{tabular}{ccc}
\hline & TN & TMD \\
\hline Mild & 3 & $11^{*}$ \\
Severe & 12 & 4 \\
\hline
\end{tabular}

${ }^{*} \mathrm{p}<0.004$; chi-square test.

Table 3. Limitations and overcome of limitations because of pain $(\mathrm{N}=30)$.

\begin{tabular}{llcc}
\hline & & TN & TMD \\
\hline Limitations & Severe & 13 & 14 \\
& Mild & 2 & 1 \\
Overcome of & By the treatment & 9 & $7^{*}$ \\
limitations & By religiosity & 3 & $6^{*}$ \\
& By accepting the disease & - & 1 \\
& By facing the pain & 1 & - \\
\hline
\end{tabular}

${ }^{*} \mathrm{p}<0.04$; chi-square test.

Table 4. Means of anxiety and depression by the HAD scale: comparison between TMD and NT (N=30).

\begin{tabular}{cccc}
\hline & TMD & TN & $\mathrm{P}$ \\
\hline Anxiety & $10.53 \pm 3.11$ & $12.8 \pm 5.10$ & 0.200 \\
Depression & $10.53 \pm 4.6$ & $11.26 \pm 5.31$ & 0.549 \\
\hline
\end{tabular}


Table 5. Means of anxiety and depression by the HAD scale: comparison among patients hospitalized, in clinical treatment, at the moment of diagnosis, and with patients from other clinics at the hospital $(N=30)$.

\begin{tabular}{|c|c|c|c|c|c|c|}
\hline \multirow[b]{2}{*}{ Facial pain patients } & \multirow[b]{2}{*}{ At diagnosis } & \multicolumn{2}{|c|}{ Anxiety } & \multicolumn{2}{|c|}{ Depression } & \multirow{2}{*}{$\frac{p}{0.753}$} \\
\hline & & $10.0 \pm 4.7$ & Mild & $10.1 \pm 5.5$ & Mild & \\
\hline & Clinical treatment & $11.8 \pm 4.4$ & Moderate & $12.7 \pm 5.2$ & Moderate & 0.221 \\
\hline & Hospitalized & $13.2 \pm 3.6$ & Severe & $9.9 \pm 3.9$ & Mild & 0.308 \\
\hline & Total & $11.7 \pm 4.3$ & Moderate & $10.9 \pm 4.9$ & Mild & 0.100 \\
\hline Other patients & Clinical treatment & $8.1 \pm 4.7$ & Mild & $6.2 \pm 4.8$ & Whitout & $0.05^{*}$ \\
\hline at the hospital & Hospitalized & $7.1 \pm 4.3$ & Subclinical & $5.2 \pm 4.0$ & Without & $0.05^{*}$ \\
\hline
\end{tabular}

*Patients with facial pain had higher scores of anxiety and depression than patients from other clinics at the hospital.

can psychologically affect the patients when compared to other clinics at the hospital.

In fact, TN is one of the worst pain syndromes and it is accompanied by severe limitations ${ }^{5}$, but also TMD patients complain about it in a similar way, as we can observe in this study (Table 3). These data may suggest that severity is not correlated to the quality of life, and mild to moderate pain also can limit daily tasks. It is important to evaluate these psychosocial aspects in facial pain patients, as their understanding can improve the treatment without underestimating lower intensities of pain, especially in chronic patients.

For TMD, surgery is considered as a possibility of pain alleviation, therefore in $\mathrm{TN}$, it is the manner to remove the pain cause, associated to the trigeminal nerve (Table 1). The multifactorial etiology of TMD 9 may confuse the patients about their diagnosis, which can be underlying the high limitations of activities that both group of patients had ${ }^{15}$. On the other hand, TN has a clearer etiology although it is still considered idiopathic ${ }^{7}$. It is important for all patients with facial pain to explain their diagnosis ${ }^{16}$. TN was well understood by the patients that participated in this study, but currently it is common to find iatrogenic procedures as dental treatments ${ }^{9,17}$.

The patients have a lot of expectation about the surgery, and it is known that religiosity and faith are important ways of coping with pain, which were found in this study. Expectations are always high in chronic pain patients and they were not associated to the intensity either, but with the duration of pain and limitations ${ }^{17}$.

In conclusion, TN and TMD had similar scores of anxiety and depression, therefore patients consider TN more se- vere than TMD. Even with higher limitations, patients with TN cope better with their disease then patients with TMD.

\section{REFERENCES}

1. Carlson CR. Psychological considerations for chronic orofacial pain. Oral Maxillofac Surg Clin N Am 2008;20:185-195.

2. Sessle BJ. Acute and chronic craniofacial pain: braistem mechanisms of nociceptiva transmission and neuroplasticity, and their clinical correlates. Crit Rev Oral Biol Med 2000;11:57-91.

3. Myers CD. Complementary and alternative medicine for persistent facial pain. Dent Clin North Am 2007;51:263-274.

4. Madland G, Feinmann C. Chronic facial pain: a multidisciplinary problem. J Neurol Neurosurg Psychiatry 2001;71:716-719.

5. Benoliel R, Eliav E. Neuropathic orofacial pain. Oral Maxillofac Surg Clin N Am 2008;20:237-254.

6. Teixeira MJ, Siqueira SRDT, Almeida GM. Percutaneous radiofrequency rizhotomy and neurovascular decompression of the trigeminal nerve for the treatment of facial pain. Arq Neuropsiquiatr 2006;64:983-989.

7. Zakrzewska JM. Diagnosis and management of non-dental orofacial pain. Dent Update 2007;34:134-139.

8. Siqueira SRDT, Nóbrega, JCM, Siqueira, JTT, Teixeira, MJ. Frequency of post-operative complications after balloon compression for idiopathic trigeminal neuralgia- prospective study. Oral Surg Oral Med Oral Pathol Oral Radiol Endod 2006;102:39-45.

9. Nobrega JC, Siqueira SR, Siqueira JT, Teixeira MJ. Differential diagnosis in atypical facial pain: a clinical study. Arq Neuropsiquiatr 2007;65:256-261.

10. Lee LT, Yeung RW, Wong MC, McMillan AS. Diagnostic subtypes, psychological distress and psychological dysfunction in sourthern Chinese people with temporomandibular disorders. J Oral Rehabil 2008;35:184-190.

11. Turp JC, Jokstad A, Motschall E, Schindler HJ, Widecker-Getaz I, Ettlin DA. Is there a superiority of multimodal as opposed to simple therapy in patients with temporomandibular disorders? A qualitative systematic review of the literature. Clin Oral Implants Res 2007;18:128-150.

12. Merskey H, Bogduk N. Classification of chronic pain. 2.Ed. Seattle: IASP Press 1994.

13. Okeson JP. Orofacial pain: guidelines for assessment, diagnosis and management. Chicago: Quintessence, 1996.

14. Botega NJ, Bio MR, Zomignani MA, Garcia JR, Pereira WAB. Transtornos de humor em enfermaria de clínica médica e validação da escala de medida (HAD) de ansiedade e depressão. Rev Saúde Pública 1980;29:137-144.

15. Cox MO. The issues and challenges of orofacial pain in the elderly. Spec Care Dentist 2000;20:245-249.

16. Siqueira SRDT, Nobrega, JCM, Valle LBS, Teixeira MJ, Siqueira JTT. Idiopathic trigeminal neuralgia: clinical aspects and dental procedures. Oral Surg Oral Med Oral Pathol Oral Radiol Endod 2004;98:311-315.

17. Oliveira MFV. Chronic orofacial pain - interface of mental health professional and the patient, family and multidisciplinary group. Rev Simbidor 2002;2:11-18. 